\title{
The Dimensions of Threat and Insecurity along the Iran's Eastern Borders with Emphasis on Drug Transit
}

\author{
Ahmad Savarrakhsh ${ }^{1}$ \& Ezzatollah Ezzati ${ }^{1}$ \\ ${ }^{1}$ Department of Geography, Science and Research Branch, Islamic Azad university, Tehran, Iran \\ Correspondence: Ahmad Savarrakhsh, department of geography, Science and Research Branch, Islamic Azad \\ university, Tehran, Iran. E-mail: Ahmadsavarrakhsh94@gmail.com
}

Received: July 9, 2016 Accepted: October 19, 2016 Online Published: November 30, 2016

doi:10.5539/jpl.v9n10p119 URL: http://dx.doi.org/10.5539/jpl.v9n10p119

\begin{abstract}
Borders are lines that separate a political unit or a country from other neighboring units or countries. The main function of the borders is determined in the interactions between surrounding countries and these mutual effects result in the governments in both sides of the border show a specific behavior towards each other.

Considering what has been pointed above, the security geography of Iran's eastern borders is highly influenced by the two neighboring countries, Afghanistan and Pakistan, which have special problems each and impact the security of Iran's eastern borders at national and regional levels.

The dimensions of threat and insecurity along the Iranian eastern borders are: drugs, terrorism, the Afghan immigrants, asylum-seekers and refugees, development of insecurity into Iran and religious actions. The drugs and drug transit, due to Iran's adjacency to the golden crescent as the producer of 80 percent of opiates in the world, being between the source (Afghanistan and Pakistan) and target (Turkey and Europe) of the path and the destructive impacts of the drugs on country, in addition to the order villages and regions and the high costs that drugs have imposed on Iran, are highly and more significantly important.

Employing analytical-descriptive method and using library resources and documents, the present study aims at clarifying the way Iran's eastern borders have been delineated, the dimensions of threat and insecurity along the aforementioned borders with emphasis on the drugs as the main case of threat and insecurity and explaining Iran's geographical realities and capacities for drug transit from this route in the country.
\end{abstract}

Keywords: drug transit, Iran's eastern borders, golden crescent, Afghanistan, Pakistan

\section{Introduction}

Borders are lines that specify the external boundaries of a political unit or a government and separate the unit from other adjacent units. The main function of borders is manifested in the interactions between the neighboring countries and changes over time. It should be said that the border lines determine a type of the behavior of humans or governments towards themselves. Governments and humans also impact the behavior and function of the border. These mutual impacts results in the governments on both sides of the borders show a specific behavior towards each other and this behavior will impact the condition and the function of the border.

When the first steps were taken for delineating new border lines in $19^{\text {th }}$ century, Iran became neighbor to counties in the east that had many problems and these problems were increased over time with Marxist coup in Afghanistan and then the leaving of the Russians and emergence of Taliban. The aforementioned changes together with the occurrence of revolution in Iran had a significant impact on the function of the common border of the two countries. The eastern Iranian borders being long (about 2000 square kilometers) together with the natural and human condition of the border regions that have geographical bonds and common historical and cultural interests, made the control of the borders difficult.

Considering the aforementioned points, the security geography of Iran's eastern borders is highly influenced by the neighboring countries, Afghanistan and Pakistan, which have their own special problems that impact the security of the eastern Iranian borders in national and regional levels. The dimensions of threat and insecurity along Iran's eastern borders are: drugs, terrorism, the Afghan immigrants, asylum-seekers and refugees, development of insecurity into Iran and religious actions. Though each of the aforementioned factors alone has high threatening and insecurity power, drugs and drug transit have higher and more significance importance due 
to having trillion dollars turnover in the world, the production of 80 percent of the world's opium and 75 of other narcotics in the world in our eastern border in Pakistan and Afghanistan that have been called golden crescent, Iran being between the source (Afghanistan and Pakistan) and target (Turkey and Europe) of the path and the destructive impacts of the drugs on country, in addition to the order villages and regions and the high costs that drugs have imposed on Iran.

\subsection{The Concept of Border}

Borders are lines that specify the external boundaries of a land under the governance of a national government. Border is the factor for identifying and separation of a political unit or a country from the adjacent units. Border gained its current meaning since the governments were formed based on the requests of the nations and border regions have been replaced by border lines. The continuous increase of the population and people's need to natural resources has resulted in governments pay attention to marking and the borders occupy the lowest amount of space as possible.

\subsection{The Role of Borders}

The borders of each country have a direct and extensive impact on the independence and territorial integrity, sovereignty, internal security, economic, cultural and ideological conditions, diplomacy and the military force of that country and this impact indicates the special importance of borders. The role of borders changes in proportion to the time. Thus, paying attention to the condition of borders has always been especially important and has had priority and governments inevitably need investment for controlling their borders.

\subsection{The Main Function of Borders}

The international borders are the factor for specifying and separation of a political-spatial unit that is independent of other adjacent units. The main function of borders becomes apparent in interaction between the adjacent countries and changes over time. Generally, the main functions of borders can be seen in the forms of economic, military-defense, the separation of the governing domain of two countries, the interaction place of the government's system, separation of surrounding communities (that have integrated and ecological identity), control of social interactions and immigration.

It should be said that border lines impact the behavior of humans and adjacent governments. Also, the governments on both cities of the border show a specific behavior towards each other under the influence of border and their behavior type impacts the condition and the function of border.

\subsection{The Begging of the Delineation of Border in Iran}

One of the first new border lines was formed in the northeast India between Iranian Empire and the British Empire. In that special period, Iran far behind the international policy and was unfamiliar with the geographical and legal complexities of determining new borders. The political weakness of the country together with the ambiguous center-surroundings relations resulted in the separation of extensive lands from Iran in Khorasan and Sistan and Baluchistan regions. Thus, Iranian eastern borders appeared in their current form.

\subsection{Iran's Eastern Borders}

The northeast, east and southeast regions together with the extensive territories that were separated from them were considered as inseparable parts in their historical perspective, due to being in their natural framework i.e. the Iranian plateau. Due to this reason, the people in these regions have high homogeneity and they are close to each other more than any other nation. The eastern Iranian border is about 184 kilometers. And $945 \mathrm{~km}$ of it is the border between Iran and Afghanistan and the rests is the border between Iran and Pakistan.

\subsection{The Border of Iran and Afghanistan}

As it was pointed out, the order line between Iran and Afghanistan was formed gradually and as the result of three governments. The aforementioned line was fixed up to 1936 and no disagreement, except two cases, has occurred. The border between Iran and Afghanistan has stretched from Zolfaghar Pass (the common border of Iran, Turkmenistan and Afghanistan) to Maleksiah Mountain and is 945 kilometers long. And the northern and central part of it has mountain ranges and highlands and there are different parts in it such as dried and extensive plains such as Sistan, Nehbandan, Petregan, Amrani, Hashtadan, Taybad and Jaam. Religiously, the people in the central strip of Sistan to Torbate Jam are Sunni and the people in both sides of the border have interactions and bonds culturally, economically, socially and religiously.

The natural and human condition of the border of Iran and Afghanistan makes it difficult to control. This border, compared with other Iranian borders has had the highest level of illegal interactions in the past three decades and has been highly damaged from this border. 


\subsection{The Border of Iran and Pakistan}

The border of Iran with Pakistan (which is in the Sistan and Baluchistan province completely) is about 900 kilometers. This border begins from Maleksiah Mountain and stretches towards south after passing several rivers, hills, plains and highlands and finally, it reaches Oman Sea around the east of Gwadar port. Similar to the border between Iran and Afghanistan, the control of the border regions between Iran and Pakistan is difficult due to its natural and human condition; and issues such as drug smuggling, propaganda activities of Wahhabis in Sunni mosques and schools and the formation of armed political groups that have targeted the people of Iranian Baluchistan increased that difficulty. Here, the border strip of Sistan and Baluchistan province, specifically its Baluchpeople are Sunni and the people of the two parts of the border (Iranian Baluchistan and Pakistani Baluchistan) have cultural, economic, social and religious bonds that add to their interactions.

\section{The Dimensions of Threat and Insecurity in Iran's Eastern Borders}

Considering what has been mentioned so far, the security geography of Iran's eastern borders are highly influenced by the two neighboring countries, Afghanistan and Pakistan. Each of these countries has special problems and issues that impact Iran's eastern borders at national and regional dimensions. What can be pointed out as threat and insecurity in this region can be an opportunity regarding security for Iran and Afghanistan at the same time. The dimensions of threat and insecurity along Iran's eastern borders can be pointed out as follow:

\subsection{Drugs}

Iran, due to its special geographical location and being between the source and destinations of drug trafficking, is considered as a victim of drugs. Adjacency to the golden crescent (Afghanistan and Pakistan ) that provides and produces more than 80 percent of the world's opiates, and having the shortest distance between the aforementioned countries and Turkey and Europe has resulted in extensive influx of mafia gangs to Iran and thus vulnerability for Iran in different security domains. Thus, Iran is the first shield against drug smuggling into Europe and the Americas. Considering the fact that there is no serious plan by Afghanistan and Pakistan for dealing with this problem, it seems that Iran has to attract international cooperation for protecting its borders and its national and regional security.

\subsection{Terrorism}

Iran and its two eastern neighbors, Afghanistan and Pakistan, somehow suffer from this dark phenomenon. The prevalence of general poverty, the lack of political and judicial justice, the lack of commitment to goodness in adjacency, the interference of transregional powers and etc. have paved the way for the expansion of the aforementioned phenomenon. Though the aforementioned reasons can be enough for the growth and development of terrorism in the region, the fact is that finding the root of terrorism in the region accurately may result in other findings that require a lot of time. The aforementioned countries being located at the southwest Asia itself intensifies the problem as no part of the world has terrorism as much as this region.

\subsection{Immigration, Asylum-Seekers and Refugees}

Iran and Afghanistan have both common historical and cultural interests and geographical cohesions. As it was explained before, the Marxist coup in followed by the Soviet forces in Afghanistan resulted in many Afghans going to Iran as refugees. The new Islamic government at the time welcomed them due to both human reasons and ideological and political reasons, without paying attention to the consequences. The leaving of the Russians and the Taliban taking power followed by US and NATO invasion of Afghanistan resulted in the continuation of this issue. The exact number of Afghan immigrants in Iran was not determined. Possible estimations have mentioned over 2 to 3 million individuals but $20 \%$ must be added to the aforementioned numbers for reaching an accurate statistic. Currently, the presence of the refugees has negative effects in terms of security, socially, politically and economically at national and regional dimensions and has resulted in new issues such as the changes in border strip perspective and the formation of non-native communities in the Iranian soil, the destruction of ranges and the environment of vulnerable areas, the change of population ratios through marriage with Iranian nationals, the spread of contagious human and animal diseases, the smuggling of Iranian commodities and currency into Afghanistan, the smuggling of drugs and arms into Iran, espionage for the Afghan government, employment in menial jobs and as workers in Iran and the formation of ethnic ghettos through purchase and owning land in border regions.

\section{The Expansion of Insecurity into Iran}

The expansion of insecurity through committing acts such as bombing, hostage taking and robbery. These insecurities that have a sociopolitical root and nature had resulted in severe concern, especially during the domination of Taliban on a significant part of Afghanistan. On the other hand, the political actions of groups 
such as Jundallah, Jaishul Adl that have been accompanied with taking of Iranian border police or other innocent people as hostage and have resulted in the taking of five Iranian border police as hostage by Jaishul Adl recently, are significant examples of these border behaviors. Between 1997 and 2000, overall 1234 individuals from the rural and urban areas of the eastern Iranian provinces were taken as hostage by the Afghans that resulted in a national action.

\subsection{Religious Actions}

Another factor impacting the security or the lack of security of borders is the ethnic and religious affiliations of the people in both sides of the border. If the religious beliefs of people living in both sides of the border are the same, it will result in more interests for people to travel between the two sides of the borders illegally, especially if the residents of the border area have a low-level culture and the common model among them is the abnormal model and against the law and norms of the general public of that country. As the majority of people on both sides of the eastern Iranian border, except Sistan, are Sunni and follower of Hanafi School, the existence of Sunni religious schools, that somehow diverges from the religious system governing Iran, will have a high effect in deviation of the religious and opposing thoughts among a part of these people.

\section{Drug Transit and Its Main Routes along Iran's Eastern Borders}

All of the things that mentioned as the dimensions of threat and insecurity along Iran's eastern borders in previous pages are highly influencing in their own place and can disturb the security geography of the eastern borders. Any insecurity along the borders of a country can have many negative effects in the internal and national security. However, among the threats that were pointed out, drug smuggling has targeted the security of the eastern borders and consequently the national security more than other things, especially as Iran's unique geographical position in terms of adjacency to one of the biggest drug production and distribution centers called the golden crescent and being on the way from the target to the destination of transit has added to the problem.

\subsection{The Golden Crescent}

The golden crescent space means Afghanistan, Pakistan and Iran. Afghanistan has been the center for production of opium and other narcotics since the past three decades in a way that it has produced 80 percent of the world's opium and 75 percent of other drugs in the world during this period. Based on the last assessment of the United Nations Office on Drugs and Crime (UNODC), 150,000 hectares of Afghanistan's agricultural lands have been under the cultivation of narcotic plants and 3700 tons of opium has been produced. Despite multiple political changes in Afghanistan, the production of narcotics has not changed much and it is still the first country in the world in terms of the production of narcotics. In addition, Afghanistan has the highest level of drug consumption based on population ratio. Based on the statistics of UNODC, currently more than 1 million people in Afghanistan consume narcotics.

The condition of Pakistan as the other eastern neighbor of Iran and the second country in this crescent is not better than Afghanistan and in 2003, 2500 hectares in this country have been under the cultivation of narcotic plants. The importance of this country is more in terms of the production of heroine as 75 percent of the heroine discovered in Europe, 25 percent of the heroine discovered in the American and 75 percent of the heroine discovered in the Arabic countries in the Persian Gulf have been produced in Pakistan and of course, with serious cooperation of Afghans.

\subsection{Appropriate Geographical Context}

The drug cartels and the organizations involved in drug trafficking need appropriate operating context so achieve success in their work. In fact the best factor is appropriate geographical context as it is considered as an essential component for activity of such groups. The geography of Iran's eastern areas, especially along the borders, has such a condition exactly. The existence of dried desert regions in the border with Afghanistan and Pakistan, from Taybad and Khvaf salt desert to Zabol and from there to Mirjavah and Gwatr, despite very unfavorable conditions naturally, has provided the smugglers with a favorable and exceptional condition in a way that the aforementioned areas are considered as ideal place for their actions.

A look at Iran's neighbors can clearly show Iran's special and unique geographical conditions for drug transit. Iran's eastern neighbors are Afghanistan and Pakistan, the former is the main producer of opium in the world and the latter is one of the main sources of world's heroine supply. The northern neighbors of Iran are some of the republics separated from Soviet Union that somehow are involved in drug smuggling. Turkey, as one of the western neighbors of Iran, is also considered as a major center for purification and turning opium into heroine and morphine and exporting it to European markets. What adds to the concerns more is the lack of cooperation of these neighbors, especially the eastern neighbors, with Iran for seriously battling with this phenomenon. Thus, 
it is not surprising that Iran's efforts in this regard has not been that much effective and even despite the illegality of the cultivation and production of any narcotic plant, the number of drug discoveries, their types and the number of addicts have been increased inside the country.

\subsection{The Main Drug Smuggling Routes}

Without doubt, the main section of the production of any product is its distribution in the consuming markets and getting it on the hands of the customers. The production of drugs is no exception to this rule. Thus, the routes for travelling and smuggling drugs and accurate knowledge of their geography are critically important for the smugglers.

\section{The Route of Iran}

Iran, as a part of the golden crescent space and due to its specific geographical position, is between the source (Afghanistan and Pakistan) and the destination (Turkey and Europe) of drug smuggling. Iran is the closest path from Afghanistan to Europe. Thus, its eastern borders are highly under the pressure of international smugglers. The eastern borders of Iran being long and being about 2000 kilometers have made Iran vulnerable to smuggling and transit of drugs. On the other hand, the natural and human condition of the border regions between Iran and Afghanistan makes the control of the border difficult. Among the Iran's borders, this border has had the highest level of illegal connections and interactions and a lot of harms have been inflicted on Iran from this area.

On the other hand, the high increase of opium poppy cultivation and consequently the high reduction of opium price have resulted in the spread of drug trade among the villagers in the border areas. In fact, the high reduction of drugs have resulted in the increase of purchasing power and in the inclination to smuggle it and a significant part of the narcotics produced in Afghanistan have been flowed to Iran that has resulted in high concerns of Iranian authorities. In the route of Iran, the smuggling of drugs from Afghanistan is mainly done to Razavi Khorasan and South Khorasan provinces. The main smuggling areas are towards north and around Taybad, near south around Birjand and towards south around Zabol region in Sistan and Baluchistan province. Another region is towards northeast and in the border with Turkmenistan that is located around Sarakhs.

It should be pointed out that a part of the drug smuggling into Iran is done through the Arab countries of the Persian Gulf. The organizers of smuggling networks that do drug transit through the route of Iran to their destinations are located outside Iran and mostly in Afghanistan, Pakistan and UAE. The smuggling of drugs into Iran from other countries in the region is rare. On the other hand, despite the multitude of drug smuggling and transit routes from Afghanistan, over half of the heroine discoveries in the world occur in southwest Asia and especially in Iran. The drug warehouses in Afghanistan are concentrated more in Nimruz, Farah and Herat provinces. And the aforementioned regions are adjacent to Iranian provinces of Razavi Khorasan, South Khorasan and Sistan and Baluchistan and this adjacency has created many security and social problems for Iran.

Also, the studies indicated that in addition to the Iranian networks in Baluchistan, some drug smuggling networks that are active in Tehran and Iran's western regions are connected to some networks in Kheibar and receive their purchased cargos in Kerman, Tabas or around Zahedan from Afghan or Pakistani networks.

Another way of heroin transit through Iran to Europe is filling 50-cenimeter reed plants with heroin and then weaving and separating reeds with high delicacy insider rugs as handicrafts in small workshops for weaving rugs in Kheibar regions. The destination of such cargos was first Cyprus and then the United States.

\section{Conclusion}

The impacts of border lines on the type of the behavior of humans and governments towards themselves and on the behavior and function of the border result in the governments on both sides of the borders show a specific behavior towards each other that will highly impact the condition and the function of the border.Considering these points, the security geography of Iran's eastern borders is highly influenced by the two neighboring countries, Afghanistan and Pakistan, which have special problems each and impact the security of Iran's eastern borders at national and regional levels. The dimensions of threat and insecurity along the Iranian eastern borders are: drugs and drug transit and smuggling, terrorism, the Afghan immigrants, asylum-seekers and refugees, development of insecurity into Iran and religious actions. And due to Iran's special geographical position, drugs and drug transit are especially important and have resulted in concerns of government authorities and police and security organizations.

Iran, being adjacent to the golden crescent that produces 80 percent of the world's opium and 75 percent of other narcotics in the world, is the shortest and most useful path between the source, Afghanistan and Pakistan, and the destinations of the drugs which are Turkey and finally Europe. Therefore, Iran's eastern borders are highly under the pressure of drug production and distribution gangs. The eastern borders of Iran being long and being about 
2000 kilometers and the existence of dried desert border areas with little vegetation and low level of water together with the small population that are scattered from the aforementioned places to the central parts of the country have created an ideal place for facilitation of drug smuggling and transit. Despite the multitude of drug smuggling and transit routes from Afghanistan and Pakistan, the transit of 90 percent of drugs, especially heroine, is done through Iran.

Basically there is no official plan or strong will for battling this dark phenomenon. Therefore any change in the conditions of the aforementioned countries will directly and highly influence Iran and its social, political, cultural and security conditions.

\section{References}

Aini, M. (2013). 50 new drug types in the way of Iran. Jaam-e-Jam Newspaper, (3869), 1-17.

Aliabadi, A. (1996). Afghanistan. Tehran: the publishing institute of the Ministry of Foreign Affairs.

Badri, M. A. (2014). the shocking statistics of the interior minister about death trade. Hamshahri Newspaper, (6173).

Booth, M. (2001). Opium: A history. Tehran: Safi Alishah.

Deilamizadeh, A. (2013). the return of heroine. Shargh newspaper, No. 1857. October, 14. pp. 1 and 6.

Deverall, R. (1955). Red China's and Dirty Drug War. Tokyo.

Dikshit, R. (1995). Political geography. New Dehli.

Ebrahimzadeh, I. (2010). spatial and environmental planning in southeast Iran. Tehran: Ettelaat publications.

Esmatollahi, M. H. (1999). The rapid Taliban movement. Tehran: Alhoda.

Ezzati, E. (2010). Iran's strategic geography (Vol. 1). Tehran: the Armed Force's Geographical Organization.

Fuller, G. (1994). The Center of the Universe: The Geopolitics of Iran. Tehran: Markaz publications.

Ghaderi, S. S. (2013). mass production of drugs under the boots of the western marines. Ettelaat Newspaper, No. 25731 (5 November,). p.16.

Glassner, M. (1993). Political geography. New York.

Hafeznia, M. R. (1987). The military geography of Khorasan. Tehran: Tarbiat Modares University.

Hafeznia, M. R. (2004, winter). the functional analysis of international border- Iran and Afghanistan's border. Modarres quarterly, (35), 69.

Jafari, A. (2005). The Identification of Iran's natural geography. Tehran: Gitashenasi.

Jahanbani, A. (1959). the history of Baluchistan and its borders. Tehran: The Geographical Organization of the Military.

Karimipour, Y. (2000). Iran and its neighbors, the source of tension and argument. Tehran: Jahad Dneshghahi of Tarbiat Moallem.

Khabaz, M. (2013). we have 300,000 drug producers. Jaam-e-Jam newspaper, No. 3831. November 4. P. 7.

Malek Mohammadi, N. (1999). A study of the reasons of Iranian nationals' illegal travels in Iran and Nakhchivan's border. DAFOS thesis, University of Police Sciences.

Mirheidar, D. (2005). The principles of political geography. Tehran: SAMT.

Mohammadi, H., \& Ghanji, M. (2006). the geopolitical challenges of drugs in the southwest Asia. Geopolitics quarterly, 2(1), 98.

Mojtahedzade, P. (2000). Geopolitical ideas and Iranian realities, the study of the relations between geography and policy in the changing world. Tehran: Nei.

Najafi, E. (2007). Exploring the reasons for illegal border travels in the Salmas Region. MA thesis, University of Police Sciences.

Prescott, G. (1979). The new trends in political geography, translated by Darre Mirheidar. Tehran: University of Tehran.

Sahand, D. (2013). from Chinese opium to Thai crystal meth in the market. Shargh newspaper, No. 1860. October 19, p. 4.

Sefidpour, A. (1962). The social impacts of opium. Tehran: Police University. 
Shah Bahrami, F. (2011-2012). The security geography of Iran's eastern borders with a view of the golden crescent. PhD dissertation at Tehran's Science and Research branch of the Islamic Azad University.

Shahni, M. (2014). drugs with new names are born. Hamshahri newspaper, No. 6172. January 25.

\section{Copyrights}

Copyright for this article is retained by the author(s), with first publication rights granted to the journal.

This is an open-access article distributed under the terms and conditions of the Creative Commons Attribution license (http://creativecommons.org/licenses/by/4.0/). 